\title{
FREQUENCY OF CHROMOSOMAL ABERRATIONS IN THE EVALUATION OF GENOTOXIC POTENTIAL OF DICYCLOHEXYLAMINE (FUMAGILLIN) IN VIVO
}

\author{
STANIMIROVIĆ Z*, STEVANOVIĆ JEVROSIMA*, KULIĆ M** and STOJIC V* \\ *Faculty of Veterinary Medicine, Belgrade \\ ${ }^{* *}$ Faculty of Medicine, East Sarajevo, Bosnia and Herzegovina \\ (Received 3. March 2006)
}

Dicyclohexylamine (fumagillin), as an antibiotic produced by fermentation of Aspergillus fumigatus, is used in human medicine for the treatment of intestinal microsporidiosis in patients with HIV infection, intestinal amebiasis and microsporidial keratoconjunctivitis. In veterinary medicine, fumagillin is effective in suppressing microsporidiosis of bees and fish. In this study, the genotoxicity of fumagillin was evaluated in mouse bone marrow cells using chromosome aberrations (CA) assay. Dicyclohexylamine was administered to mice by gavage in a dose of $25,50,75 \mathrm{mg} / \mathrm{kg} \mathrm{b.w.,} \mathrm{with}$ water-sugar syrup as the negative control and cyclophosphamide as the positive control (40 mg/kg b.w.) Significantly increased frequency $(p<0.01$ or $p<0.001)$ of numerical chromosomal aberrations (aneupliodies and polyploidies) and structural chromosomal aberrations of gaps, breaks and centric rings were observed only at the highest experimental dose of dicyclohexylamine, compared with the negative control. However, in point of induction of $R b$ translocations, both the median (50 mg/kg b.w.) and highest (75 mg/kg b.w.) experimental dose showed a significant $(p<00.001)$ increase $(7.12 \pm$ 0.26 and $9.00 \pm 0.10$, respectively) in comparison with the negative control $(0.00 \pm 0.00)$. Chromosomes 4 and 19 participated in these $R b$ translocations. These results suggest that dicyclohexilamine (fumagillin) has genotoxic potential in mammal in vivo chromosomal aberration (CA) test system.

Key words: dicyclohexylamine (fumagillin), honey bee, nosemadisease, genotoxicity, chromosome aberrations (CA), Robertsonian chromosome $R b$ (4.19).

\section{INTRODUCTION}

Dicyclohexylamine (fumagillin) is an antibiotic isolated from Aspergillus fumigatus. Currently, it is the only drug effective in suppresing cryptosporidiosis and microsporidiosis caused by Enterocytozoon bieneusi. These are common and frequently fatal infections in AIDS sufferers (Molina et al., 2000; Conteas et al, 
2000). Fumagillin is also a strong antiparasitic and amoebicidal compound (McCowen et al., 1951; Killough et al., 1952) and has acquired importance in veterinary medicine against microsporidiosis of bees and fish (Katznelson and Jamieson, 1952; Bailey, 1953; El-Matbouli and Hoffmann, 1991; Morris et al., 2003).

It is known that dicyclohexylamine is quite stable in honey bee hives (Furgala, 1962). Furthermore, investigations of Assil and Sporns (1991) showed that fumagillin was very stable in honey at elevated temperatures (stable for at least 35 days at $80^{\circ} \mathrm{C}$ ). The use of fumagillin is permitted in the EU and the USA (EMEA, 2000; FDA, 2005), but the maximum residue level (MRL) is not affirmed neither in the EU, nor in the USA.

Fumagillin, fed in syrup, has proven to be especially effective in suppressing nosema in overwintered honey bee colonies and newly established packages, as it attacks the actively multiplying disease-producing parasites in the gut of the bee. Since fumagillin is not effective against dormant $N$. apis spores, treatment with this drug will not completely eliminate the disease from the colony. The infection will continue after all the medicated syrup has been consumed (Mladjan et al., 2000a,b). In addition, adverse effects on bees after treatment with fumagillin were described. Mitochondria from the corpora allata of Nosema-infected honeybees, after treatment with fumagillin, had a higher electron density in the mitochondrial matrix and smaller diameter than those from untreated honey bees (Liu, 1990a). After treatment with fumagillin, secretion granules in the hypopharyngeal glands of Nosema-infected honey bees were increased in size, slightly electron dense, and the granular content was homogenous. Some of these granules were also partially crystallized. These ultrastructural changes in the secretion granules of fumagillin treated bees are probably associated with a change in secretory activity of the glands (Liu, 1990b). Moreover, fumagillin significantly increases the mortality of bees and significantly increases the counts of yeasts in comparison with the control (Rada et al., 1997).

Dicyclohexylamine has also been proposed for suppression of other microsporidian parasites in the invertebrates and vertebrates. Thus, Zbinden et al. (2005) presented a protocol for inhibiting vertical transmission of the microsporidian parasite Octosporea bayeri in the freshwater crustacean Daphnia magna. Fumagillin, administered in the diet, has been used to treat microsporidiosis in fish, because studies found it to be effective against some myxozoan parasites, including Myxobolus cerebralis (Myxosporea), the causative agent of whirling disease in many fish species (El-Matbouli and Hoffmann, 1991; Karagouni et al., 2005) and Tetracapsuloides bryosalmonae (Malacosporea), the causative agent of proliferative kidney disease of chinook salmon Oncorhynchus tshawytscha (Hedrick et al., 1988; Kent and Dawe, 1994) and rainbow trout Oncorhynchus mykiss (Le Gouvello et al., 1999; Morris et al., 2003). However, in the more rigorous tests required for the U.S. Food and Drug Administration approval, it was found to be ineffective (Gilbert and Granath, 2003).

In humans, fumagillin was used more than 40 years ago for the treatment of intestinal amebiasis (McCowen et al., 1951; Killough et al., 1952). Fumagillin is effective when used topically in the treatment of microsporidial 
keratoconjunctivitis, as well (Roseger et al., 1993; Wilkins et al., 1994). The results of Molina et al. $(2000,2002)$ supported the use of oral fumagillin as an effective treatment for chronic Enterocytozoon bieneusi infection in patients with AIDS and other types of immunodeficiency, but further work is necessary to fully establish proper therapeutic protocols and manage side effects of the treatments (Conteas et al., 2000).

However, according to EMEA (2000), indications for use of fumagillin are only nosemosis of honey bees and proliferative kidney disease of trouts. For treatment of Nosema infections in honey bees fumagillin is the only chemical registered.

Data refering to genotoxic effects of fumagillin were obtained by in vitro investigations and the results were positive (Stoltz et al., 1970; Stanimirovic et al., 1999; Stevanovic et al., 2000) or negative (Purchase et al., 1978; Mortelmans et al., 1986; Heil et al., 1996). In addition, there are no references regarding genotoxic effects of fumagillin in vivo (Toxicological Evaluation, 2000).

Bearing in mind all the aforementioned, investigations of the genotoxic effects of fumagillin in vivo are necessary, even more as these effects significantly depend on test models, on chosen doses of the tested substance, and its interaction with other endogenous and exogenous factors (Ames, 1989; Albertini et al., 2000; Norppa, 2003; Stanimirovic et al., 2005).

The objective of this study was to evaluate and characterize possible genotoxic effects of dicyclohexylamine (fumagillin) in vivo using different doses which are in the therapeutic range used in beekeeping. In the undertaken cytogenetic assay the frequency of chromosome aberrations (CA) was monitored. In addition, we identified chromosomes which take part in the formation of chromosomal rearrangements which occured as a consequence of dicyclohexylamine activity.

\section{MATERIAL AND METHODS}

The genotoxic effects of dicyclohexylamine (Fumagillin-ET, 3/0-05-009/001JKL 022; Evrotom, Ruma, SCG) were investigated in bone marrow cells of BALB/C strain mice, using the chromosomal aberration (CA) assay.

Three experimental doses of dicyclohexylamine (fumagillin) were tested: 25, 50 and $75 \mathrm{mg} / \mathrm{kg}$ b.w. The median experimental dose of $50 \mathrm{mg} / \mathrm{kg}$ corresponds to the therapeutic dose-range of fumagillin in beekeeping, since the recommended fumagillin dose for honey bees is $26 \mathrm{mg}$ fumagillin/L (Webster, 1994).

Fumagillin does not dissolve readily in water. To prepare medicated sugar syrup, it is recommended to mix fumagillin in small amounts of warm water (not above $32-34^{\circ} \mathrm{C}$ ) and stir into a paste, then add the prepared water-sugar syrup gradually and shake container occasionally. The antibiotic mixture should be admixed with water-sugar syrup shortly before use.

The experimental design for chromosomal aberration (CA) test included three groups: positive control, negative control, and experimental group. The experimental group was divided into three subgroups based on selected doses of 
fumagillin. All groups had six animals per dose/group (male sex). Our experimental design was conducted in two cycles. We used BALB/c mice 6 weeks of age with average weight of $19 \pm 2 \mathrm{~g}$. Animals were kept under uniform conditions and were housed under 12/12-h photoperiod at constant temperature $\left(21^{\circ} \mathrm{C}\right)$ with free access to standard laboratory chow and water.

Experimental doses were obtained by dissolving dicyclohexylamine (fumagillin) in 1:1 water-sugar syrup, as in the formulation usually used in beekeeping, and orally administered in mice. Since tested doses of fumagillin were 25,50 and $75 \mathrm{mg} / \mathrm{kg}$ b.w., each mice received $0.55,1.1$ and $1.65 \mathrm{mg} / \mathrm{kg}$ b.w. respectively in the 7 -day treatment, that is $0.08,0.157$ and $0.236 \mathrm{mg} / \mathrm{kg} \mathrm{b.w}$. respectively per mice per day.

The negative control group was treated per os with water-sugar syrup. A known mutagen, cyclophosphamide at a dose of $40 \mathrm{mg} / \mathrm{kg} \mathrm{b.w}$. was used as the positive control group due to its known clastogenic and mutagenic features (Anderson et al., 1995). Cyclophosphamide was intraperitoneally (i.p.) administered, and the volume injected was $0.01 \mathrm{~mL} / \mathrm{g} \mathrm{b.w.} \mathrm{All} \mathrm{animals} \mathrm{received}$ daily i.p. treatments for a 7-day period.

Cytogenetic analysis was performed by direct method of rinsing long bone marrow (femur and tibia) according to Hsu and Patton (1969) as modified by Zimonjic et al. (1990). Slides were made by the flame-dried technique and later stained with Giemsa (Sigma Chemical Co., St. Louis, MO). G-banding of chromosomes was done by the tripsin method of Seabright (1971) and Ronne (1991). Chromosomes and chromosomal bands were identified on the basis of criteria established by the Committee on Standardized Genetic Nomenclature for Mice (1979) and Cowell's photoatlas of mouse chromosomes (Cowell, 1984), in order to identify chromosomes which take part in the formation of Robertsonian (Rb) metacentric chromosomes.

We analyzed 600 well-spread metaphases for each treatment to detect the presence of chromosomal aberrations (CA). Statistical analyses was carried out with the software programme Statistica 6.0 using the Analysis of Variance (ANOVA) and the Student's $t$-test and LSD-test.

\section{RESULTS}

The effects of dicyclohexylamine (fumagillin) were evaluated in bone marrow cells of BALB/c strain mice by monitoring the chromosome aberrations (CA). It was established by cytogenetic analysis that there was an increase in the frequency of numerical and structural chromosome aberrations in the mouse bone marrow cells after 7-day per os treatment with increasing doses of fumagillin $(25,50$ and $75 \mathrm{mg} / \mathrm{kg} \mathrm{b.w.)}$ in comparison with the negative control. Fumagillin showed the ability to induce numerical aberrations of aneuploidy and poliploidy type and the following types of structural chromosome aberrations: gaps, breaks, centric rings and Robertsonian (Rb) translocations (Table 1) (Figures 1, 2 and 3).

Significantly increased frequency $(p<0.01$ or $p<0.001)$ of numerical chromosomal aberrations (aneupliodies and polyploidies) and structural chromosomal aberrations of gaps, breaks and centric rings were observed only at 
Stanimirović $Z$ et al.: Frequency of chromosomal aberrations in

the evaluation of genotoxic potential of dicyclohexylamine (fumagillin) in vivo

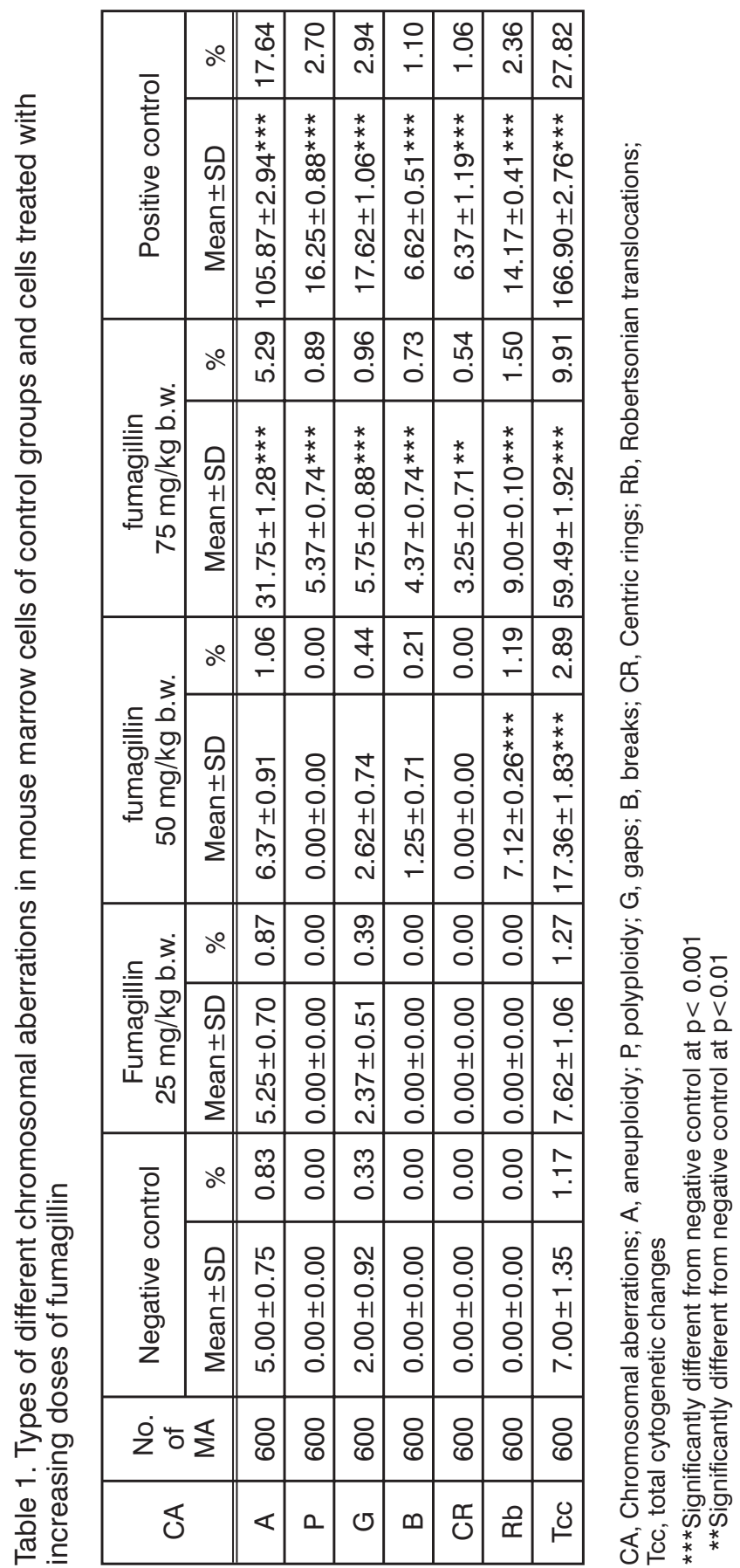




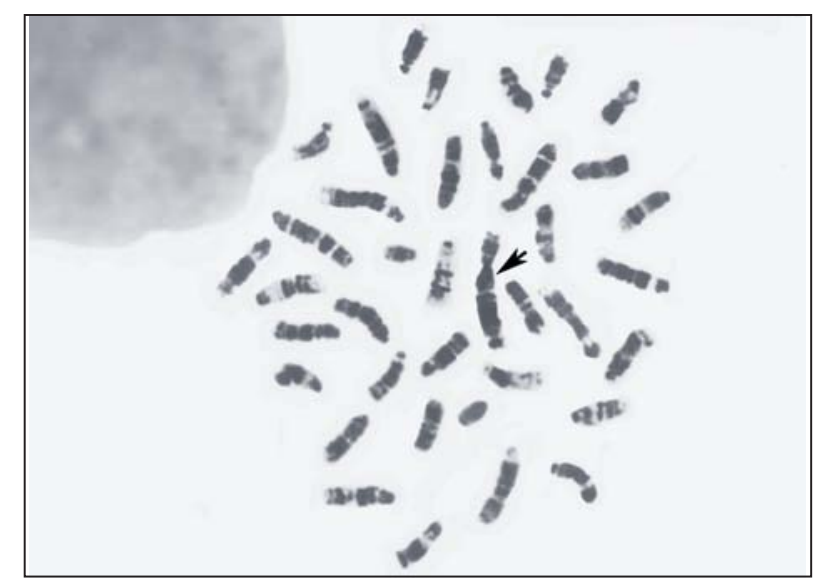

Figure 1. G-band of chromosomes of the mouse treated with the highest dose of fumagillin (75 mg/kg b.w.) - arrow indicates the Robertsonian chromosome Rb (4.19)

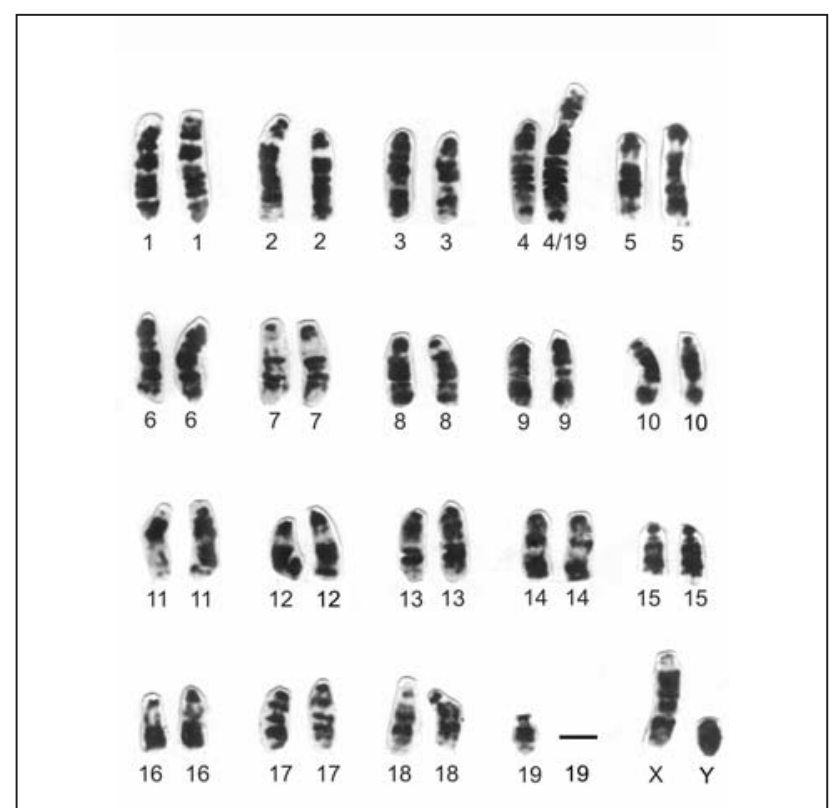

Figure 2. G-banded karyogram of the mouse heterozygous for the Robertsonian translocation $\mathrm{Rb}(4.19)$ (animal treated with the highest dose of fumagillin $75 \mathrm{mg} / \mathrm{kg}$ b.w.) 
the highest experimental dose of dicyclohexylamine (75 mg/kg b.w.) compared with the negative control (Table 1). However, in point of induction of $\mathrm{Rb}$ translocations, both the median (50 mg/kg b.w.) and the highest $(75 \mathrm{mg} / \mathrm{kg} \mathrm{b.w.)}$ experimental dose showed a significant $(p<0.001)$ increase $(7.12 \pm 0.26$ and $9.00 \pm 0.10$, respectively) in comparison with the negative control (Table 1). After the completion of G-band analyses and chromosome identification it was observed that chromosomes 4 and 19 had participated in the formation of $\mathrm{Rb}$ translocations (Figures 1, 2 and 3). The noticed structural Rb (4.19) aberration was in a heterozygous state and identified in 5 animals: two of 12 animals treated with the median dose $(50 \mathrm{mg} / \mathrm{kg} \mathrm{b.w.)}$ of fumagillin and 3 of 12 animals treated with the highest dose of fumagillin $(75 \mathrm{mg} / \mathrm{kg} \mathrm{b.w.})$.

Regarding total cytogenetic changes (Table 1), a significant increase $(p<0.001)$ was observed in both, the median dose group $(17.36 \pm 1.83)$ and the highest dose group $(59.49 \pm 1.92)$ compared to the negative control group (7.00 \pm 1.35$)$.

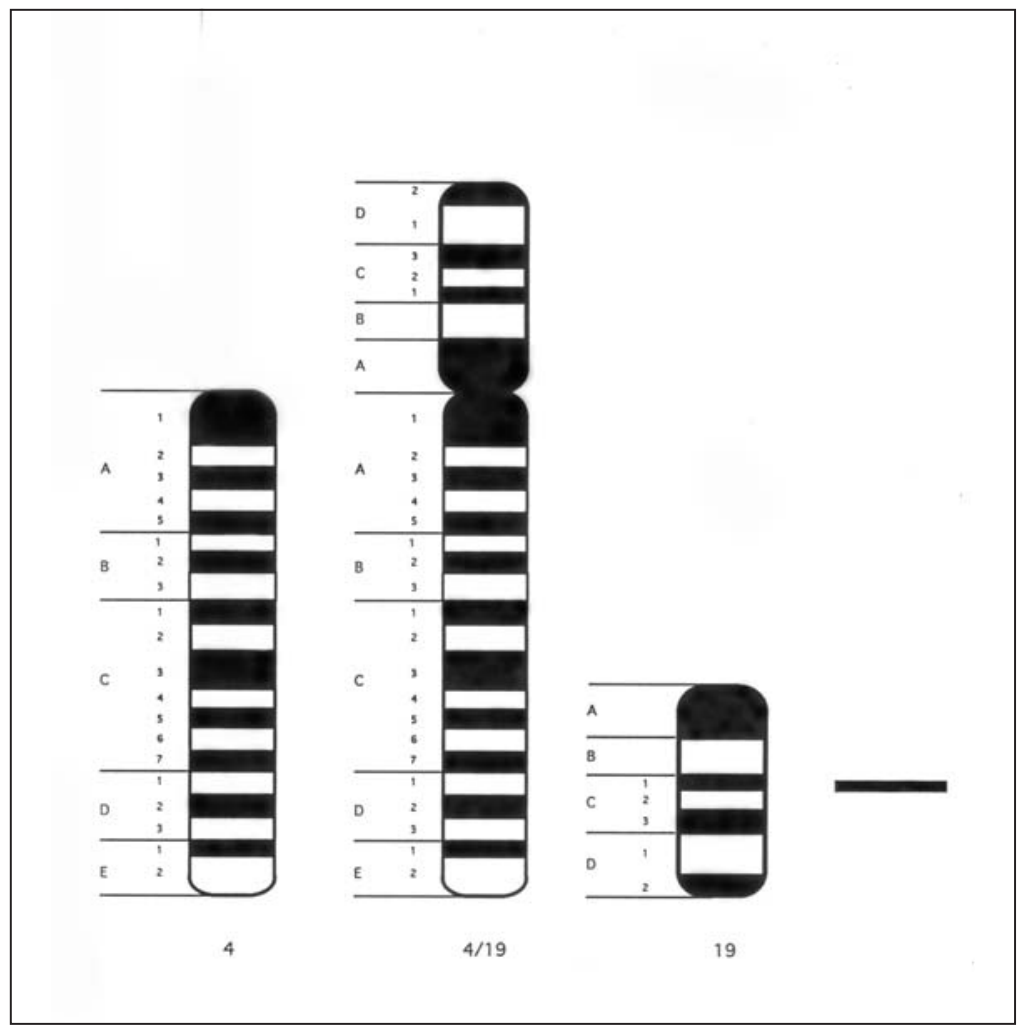

Figure 3. Distribution of G-bands in the idiogram of the Robertsonian chromosome $\mathrm{Rb}$ (4.19) of the BALB/c mouse 


\section{DISCUSSION}

Dicyclohexylamine (fumagillin) is an antibiotic originally used against fungal Nosema apis infections in honey bees (Katznelson and Jamieson, 1952; Bailey, 1953) and its residues from honey and other food based on honey bee products, can easily reach consumers (including children, adolescents, convalescents, chronic patients and the elderly) (Stanimirovic et al., 1999; Stevanovic et al., 2000) considering its high stability in such diets (Assil and Sporns, 1991) Furthermore, topical fumagillin is suggested for treatment of ocular infection caused by microsporidia (Roseger et al., 1993; Wilkins et al., 1994); whilst oral fumagillin is an effective treatment for chronic Enterocytozoon bieneusi infection in patients with AIDS (Molina et al., 2000, 2002; Conteas et al., 2000). Having in mind all specified informations, it is obvious that evaluation of genotoxic effects of fumagillin is needful, even more as the available data refering to genotoxic effects of fumagillin (dicyclohexylamine) obtained by in vitro investigations are equivocal, i.e. positive (Stoltz et al., 1970; Stanimirovic et al., 1999; Stevanovic et al., 2000) or negative (Purchase et al., 1978; Mortelmans et al., 1986; Heil et al., 1996) and there are no references regarding genotoxic effects of fumagillin in vivo (Toxicological Evaluation, 2000).

The results of this study points to an ability of tested doses of dicyclohexylamine (fumagillin) to induce numerical and structural chromosome aberrations in vivo, particularly the median and the highest doses (Table 1). Thus, the median dose of fumagillin $(50 \mathrm{mg} / \mathrm{kg} \mathrm{b.w.)} \mathrm{significantly}(p<0.001)$ increased the frequency of Rb translocations; whilst the highest dose of fumagillin $(75 \mathrm{mg} / \mathrm{kg}$ b.w.) increased the frequency of aneuploidy, polyploidy, gaps, breaks and $\mathrm{Rb}$ translocations with a signification level of $p<0.001$, and centric rings with a signification level of $p<0.01$.

Since data regarding genotoxic effects of dicyclohexylamine (fumagillin) in vivo are lacking (Toxicological Evaluation, 2000) there is no possibility for direct comparasion of our results. However, if we compare them to the results of Van Went-de Vries (1975) who investigated cyclohexilamin, we can notice certain agreement, but some disagreement as well. Van Went-de Vries et al. (1975) observed a significant increase in structural chromosome aberrations (ring chromosome, exchange figures, fragments and breaks) in Chinese hamsters treated with cyclohexilamine $(\mathrm{CHA})$ at a dose of $200 \mathrm{mg} / \mathrm{kg} /$ day. However, there was no significant increase in aneuploid or polyploid cells in the same study (Van Went-de Vries et al., 1975); whilst fumagillin (dicyclohexylamine) in our study showed the ability to induce aneuploidies and polyploidies. Our results showed a significant increase $(p<0.001)$ in frequency of these aberrations only in the highest dose group ( $75 \mathrm{mg} / \mathrm{kg}$ b.w.). These findings are in accordance with the previous in vitro findings of Stanimirovic et al. (1999) and Stevanovic et al. (2000).

Furthermore, in vitro investigations of dicyclohexylamine gave no indication of its genotoxic potential in the Salmonella/microsome assay using Salmonella typhimurium strains TA 98, TA 100, TA 1535 and TA 1538 (Purchase et al., 1978; Mortelmans et al., 1986). Moreover, investigations of the DNA-damaging effect of dicyclohexylamine in the UMU test, using Salmonella typhimurium strain TA 
1535/pSK1002 and in the DNA synthesis inhibition test in HeLa S3 cells, gave no indication that dicyclohexylamine had a damaging effect on DNA (Heil et al., 1996); which is rather surprising considering that fumagillin has primarily two epoxide structures capable of alkylating proteins involved in the packaging of DNA (Birch and Hussein, 1969) thereby establishing conditions for damaging DNA. However, in a cytogenetic study obtained by Stoltz et al. (1970) lymphocytes from human blood samples incubated with dicyclohexylamine sulfate for 5- and 24-hours showed a concentration-depended increase in aberration rate from approx. $6 \%$ in the controls to approx. $16 \%$ in the experimental groups.

In addition, the National Toxicology Program (National Toxicology Program $2006 a, b)$ reports a positive genotoxic effect in the Salmonella test for dicyclohexylamine nitrite (National Toxicology Program 2006a) and negative for dicyclohexylamine (National Toxicology Program 2006b). Besides, there are references about genotoxic effects of secondary metabolites (gliotoxin and verruculogen) of Aspergillus fumigatus, the fungus that produces fumagillin, too. Namely, gliotoxin induced DNA adduct formation (Golden et al., 1998) and has been proven to be genotoxic in various in vitro test systems (Nieminen et al., 2002); whilst verruculogen was genotoxic in the Salmonella/mammalian microsome assay (Sabater-Vilar et al., 2003).

In our study, in a certain number of animals treated with the median and the highest doses of fumagillin (50 and $75 \mathrm{mg} / \mathrm{kg} \mathrm{b.w}$ ), after G-band analyses, we observed that acrocentric chromosomes 4 and 19 participated in the formation of unusual Rb metacentrics. However, even though such a type of chromosome aberration was not found in the negative control group, we cannot claim for certain that the observed $\mathrm{Rb}$ (4.19) chromosome is a consequence of genotoxic activity of fumagillin, considering the fact that some Rb chromosomes can be found in the genome of laboratory mice, and are probably derived from a feral mouse (Gropp and Winking, 1981). This is supported by the statement that nucleolus organizer regions (NORs) do have some influence upon the frequency of $\mathrm{Rb}$ translocations, since in mouse cell lines chromosomes with active NORs are significantly represented in Rb chromosomes (Miller et al., 1978). From laboratory mice it is known that chromosomes $12,15,16,18$ and 19 may bear NORs proximal to the centromeric heterochromatin (Winking et al., 1988).

In addition, according to Gropp and Winking (1981), there are breakpoints prior to $\mathrm{Rb}$ translocation located within the paracentromeric heterochromatin or C-band positive material. This fact seems encouraging with regard to our finding of Rb chromosome 4.19, since that in our study a significant increase (p.001) in the frequency of gaps and brakes has been observed in animals treated with the highest dose of fumagillin $(75 \mathrm{mg} / \mathrm{kg}$ b.w.). These structural changes may have occurred in paracentromeric heterochromatin or C-band positive material of chromosome 4 and 19 which could consequently result in subsequent occurrence of $\mathrm{Rb}(4.19)$.

However, our attempts to identify chromosomes which took part in the formation of centric rings failed.

Finally, our results considering the increases CA frequencies induced by fumagillin, lead to the conclusion that fumagillin residues in honey, even at doses 
as tested in our study, if they are consumed by the elderly, chronic patients and convalescents, could have an additional harmful influence on their health condition. In addition, there could be an effect on the absorption of drugs already used because ageing and various xenobiotics reduce the capacity for drugmetabolising enzymes (Ingelman-Sundberg, 2001; Bajic et al., 2004). It should be also emphasized that the possible ability of dicyclohexylamine (fumagillin) to induce $\mathrm{Rb}$ translocations should not be neglected. The induction of these aberrations in germ cells of sexually matured individuals - consumers of honey with residues - could bring about reproductive problems as chromosome segregations in trivalent mitotic figures, which enclose heterozygous $\mathrm{Rb}$ chromosome, could arise 6 theoretically possible combinations of gametes (1/6 normal, $1 / 6$ balanced and $4 / 6$ unbalanced gametes with asomy or disomy), all this in view of known effects of $\mathrm{Rb}$ translocations on mammal fertility (Gustavson, 1977; Soldatovic et al., 1994; Stanimirovic, 1995; Vucinic et al., 1996; Eaker et al., 2001).

In a conclusion, it is necessary to educate beekeepers with regard to the use of fumagillin for the purpose of consumer safety, even more that fumagillin has the ability to induce Rb translocations and other types of structural chromosomal aberrations which consequently could result in reproductive problems in honey consumers. A similar caution should be taken with patients treated with fumagillin against microsporidia. Additionally, it is necessary to perform furher investigations of dicyclohexylamine in order to reveal other potential adverse effects of the substance, even more as MRL for dicyclohexylamine is not affirmed neither in the EU, nor in the USA.

\section{ACKNOWLEDGEMENT:}

This study was supported by the Serbian Ministry of Science and Environmental Protection, Grant No. 143022 (Ecophysiological and genetic investigations of domestic animals and bees for the purpose of increasing reproductive traits and disease resistance).

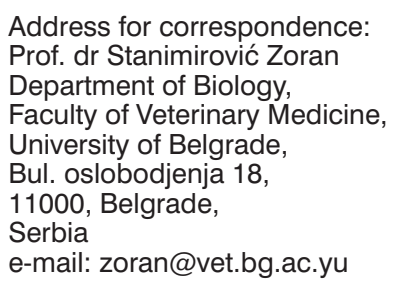

\section{REFERENCES}

1. Albertini RJ, Anderson D, Douglas GR, Hagmar L, Hemminki K et al., 2000, IPCS guidelines for the monitoring of genotoxic effects of carcinogens in humans, Mutat Res, 463, 111-72.

2. Ames BN, 1989, Mutagenesis and carcinogenesis: Endogenous and exogenous factors, Environ Molec Mut, 14, (Suppl. 16) 66-77.

3. Anderson D, Bishop JB, Garner RC, Selby PB, 1995, Cyclophosphamide: review of its mutagenicity for an assessment of potential germ cell risk, Mutat Res, 330, 115-8.

4. Assil HI, Sporns P, 1991, ELISA and HPLC methods for analysis of fumagillin and its decomposition products in honey, J Agric Food Chem 39, 2206-13. 
5. Bailey L, 1953, Effect of fumagillin upon Nosema apis (Zander), Nature, 171, 212-3.

6. Bajic V, Stanimirovic Z, Stevanovic J, 2004, Genotoxicity potential of 8-Cl-Cyclic Adenosine Monophosphate Assessed with Cytogenetic Test In Vivo, Arch Med Res, 35, 209-14.

7. Birch AJ, Hussain SF, 1969, Studies in relation to biosynthesis. Part 38. A preliminary study of fumagillin, $J$ Chem Soc, 11, 1473-4.

8. Committee on Standardized Genetic Nomenclature for Mice, 1979, New rules for nomenclature of genes, chromosome anomalies and inbred strain of mouse, Mouse News Letter, 61, 4-11.

9. Conteas CN, Berlin OG, Ash LR, Pruthi JS, 2000, Therapy for human gastrointestinal microsporidiosis, Am J Trop Med Hyg, 63, 121-7.

10. Cowell JK, 1984, A photographic representation of the variability of the G-banded structure of the chromosomes of the mouse karyotype, Chromosoma, 89, 294-320.

11. Eaker S, Pyle A, Cobb J, Handel MA, 2001, Evidence for meiotic spindle checkpoint from analysis of spermatocytes from Robertsonian-chromosome heterozygous mice, J Cell Sci, 114, 2953-65.

12. El-Matbouli M, Hoffmann RW, 1991, Prevention of experimentally induced whirling disease in rainbow trout Oncorhynchus mykiss by Fumagillin, Dis Aquat Organ 10, 109-13.

13. EMEA-The European Agency for the Evaluation of Medicinal Products, Veterinary Medicines and Information Technology, EMEA/CVMP/411/00-FINAL, Committee for Veterinary Medicinal Products, Update of the Position Paper on Availability of Veterinary Medicines agreed on 21 June 2000.

14. FDA Approved Animal Drug Products Online Database System Drug Product Abstract, http://meds.glowingpets.com/veterinary/2dawnk 9-23.html. Chapter 1.2 - Tradenames and Sponsors - Arranged by NADA Number: 009-252, Fumidil B, Mid-Continent Agrimarketing, Inc. 009-339, Carafen Cough, http://www.census.gov/foreign-trade/schedules/b/2005/alpha-f.html

15. Furgala $B, 1962$, Residual fumagillin activity in sugar syrup stored by wintering honeybee colonies, $J$ Apic Res 1, 35-7.

16. Gilbert MA, Granath WO Jr, 2003, Whirling disease and salmonid fish: life cycle, biology, and disease, $J$ Parasitol, 89, 658-67.

17. Golden MC, Hahm SJ, Elessar RE, Saksonov S, Steinberg JJ, 1998, DNA damage by gliotoxin from Aspergillus fumigatus, Mycoses, 41, 97-104.

18. Gropp A, Winking H, 1981, Robertsonian translocations: cytology, meiosis, segregation pattern and biological consequences of heterozygosity, In: Berry RJ, editor, Biology of the House Mouse, Academic Press, New York/London, 141-81.

19. Gustavson I, 1977, Distribution and effects of the $1 / 29$ Robertsonian translocation in cattle, J Dairy Sci, 62, 825-35.

20. Hedrick RP, Groff JM, McDowell T, 1988, Oral administration of Fumagillin DCH protects chinook salmon Oncorhynchus tshawytscha from experimentally-induced proliferative kidney disease, Dis Aquat Organ, 4, 165-8.

21. Heil J, Reifferscheid G, Waldmann P, Leyhausen G, Geurtsen W, 1996, Genotoxicity of dental materials, Mutat Res, 368, 181-94.

22. Hsu TC, Patton GL, 1969, Bone marrow preparations for chromosome studies, In: Benirische K, editor, Comparative mammalian cytogenetics, Springer-Verlag, Berlin, 1-395.

23. Ingelman-Sundberg M, 2001, Genetic variability in susceptibility and response to toxicants, Toxicol Lett, 120, 259-68.

24. Karagouni E, Athanassopoulou F, Lytra A, Komis C, Dotsika E, 2005, Antiparasitic and immunomodulatory effect of innovative treatments against Myxobolus sp. infection in Diplodus puntazzo, Vet Parasitol, 134, 215-28.

25. Katznelson H, Jamieson CA, 1952, Control of Nosema disease of honey-bees with fumagillin, Science, 115, 70-1.

26. Kent ML, Dawe SC, 1994, Efficacy of fumagillin Dch\# against experimentally-induced Loma salmonae (Microsporea) infections in chinook salmon Oncorhynchus tshawytscha, Dis Aquat Organ, 20, 231-3.

27. Killough JH, Magill GB, Smith RC, 1952, The treatment of amebiasis with fumagillin, Science, 115, 71-2. 
28. Le Gouvello R, Pobel T, Richards RH, Gould C, 1999, Field efficacy of a 10-day treatment of fumagillin against proliferative kidney disease in rainbow trout Oncorhynchus mykiss, Aquaculture, 171, 27-40.

29. Liu TP, 1990a, Ultrastructure of mitochondria in the corpora allata of honeybees infected by Nosema apis before and after treatment with anti-Nosema drugs, Tissue and Cell, 22, 511-5.

30. Liu TP, 1990b, Ultrastructural changes in the secretion granules of the hypopharyngeal glands of the honeybee infected by Nosema apis and after treatment with fumagillin, Tissue and Cell, 22, 523-31.

31. McCowen MC, Callender ME, Lawlis JF Jr, 1951, Fumagillin (H-3), a new antibiotic with amebicidal properties, Science, 113, 202-3.

32. Miller OJ, Miller DA, Tantravahi R, Dev VG, 1978, Nucleolus organizer activity and the origin of Robertsonian translocations, Cytogenet Cell Genet, 20, 40-50.

33. Mladjan V, Todorovic D, Lolin M, 2000a, Preventive action of fumagillin on the degree of infection with Nosema apis in the digestive tract of bees, Acta Vet, 50, 241-52.

34. Mladjan V, Todorovic D, Lolin M, 2000b, Therapeutic effects of fumagillin and first appearance of Nosema apis spores following infection, Acta Vet, 50, 253-62.

35. Molina JM, Goguel J, Sarfati C, Michiels JF, Desportes-Livage I et al., 2000, Trial of oral fumagillin for the treatment of intestinal microsporidiosis in patients with HIV infection, AIDS, 14, 1341-8.

36. Molina JM, Tourneur M, Sarfati C, Chevret S, de Gouvello A et al., 2002, Fumagillin treatment of intestinal microsporidiosis, N Engl J Med, 346 (2002) 1963-9.

37. Morris DJ, Adams A, Smith P, Richards RH, 2003, Effects of oral treatment with TNP-470 on rainbow trout (Oncorhynchus mykiss) infected with Tetracapsuloides bryosalmonae (Malacosporea), the causative agent of proliferative kidney disease, Aquaculture, 221, 51-64.

38. Mortelmans K, Haworth S, Lawlor T, Speck W, Tainer B, Zeiger E, 1986, Salmonella mutagenicity tests: II. Results from testing of 270 chemicals, Environ Mutagen, 8, Suppl 7, 1-119.

39. National Toxicology Program (2006a), http://ntp.niehs.nih.gov/index.cfm?objectid=6DE0B88CF1F6-975E-7A19428A3AD94D85

40. National Toxicology Program (2006 b) http://ntp.niehs.nih.gov/index.cfm?objectid=6DE0E43FF1F6-975E-7B0FA8000D056A43

41. Nieminen SM, Maki-Paakkanen J, Hirvonen MR, Roponen M, von Wright A, 2002, Genotoxicity of gliotoxin, a secondary metabolite of Aspergillus fumigatus, in a battery of short-term test systems, Mutat Res, 520, 161-70.

42. Norppa H, 2003, Cytogenetic biomarkers and genetic polymorphisms, Toxicol Lett, 144, (Suppl. 1) 25.

43. Purchase IFH, Longstaff E, Ashby J, Styles JA, Anderson D et al., 1978, An evaluation of 6 short-term tests for detecting organic chemical carcinogens, Br J Cancer, 37, 873-959.

44. Rada V, Machova M, Huk J, Marounek M, Duskova D, 1997, Microflora in the honeybee digestive tract - counts, characteristics and sensitivity to veterinary drugs, Apidologie, 28, 357-65.

45. Ronne M, 1991, High resolution banding present aspects, Gen Sel Evol, 23, (Suppl. 1) 49s-55s. Elsevier / INRA.

46. Roserger DF, Serdaravic ON, Evlandson RA, Bryan RT, Schwartz DA et al., 1993, Successful treatment of microsporidial keratoconjunctivitis with topical fumagillin in a patient with AIDS, Cornea, 12, 261-5.

47. Sabater-Vilar M, Nijmeijer S, Fink-Gremme/s J, 2003, Genotoxicity assessment of five tremorgenic mycotoxins (fumitremorgen B, paxilline, penitrem A, verruculogen, and verrucosidin) produced by molds isolated from fermented meats, J Food Prot, 66, 2123-9.

48. Seabright M, 1971, A rapid banding technique for human chromosomes, Lancet, 2, 971-972.

49. Soldatovic B, Stanimirovic Z, Vucinic M, Djokic D, Vucicevic M, 1994, Robertsonian fusion in a simmental cow-bull mother (part II), Acta Vet, 44, 173-8.

50. Stanimirovic Z, 1995, Comparative analyses of natural and induced polymorphism of chromosomes in the species Mus musculus, Linne (1758), PhD thesis, Faculty of Biology, University of Belgrade. 
51. Stanimirovic Z, Stevanovic J, Pejovic D, 1999, Analysis of genotoxic effects of fumagillin-ET, In: Proceedings of the 29th Annual Meeting of the European Environmental Mutagen SocietyEEMS-99, vol. 85, Copenhagen, 44-5.

52. Stanimirovic Z, Stevanovic J, Jovanovic S, Andjelkovic M, 2005, Evaluation of genotoxic effects of Apitol ${ }^{\circledR}$ (cymiazole hydrochloride) in vitro by measurement of sister chromatid exchange, Mutat Res, 588, 152-7.

53. Stevanovic J, Stanimirovic Z, Djelic N, Djurkovic Snezana, 2000, Is the application of fumagillin in nosemosis treatment acceptable from a genotoxicological point of view. In: Trailovic D, Lazarevic M, editors, Proceedings of the 2nd Symposium in Animal Clinical Pathology and Therapy Clinica Veterinaria 2000 , June 12-16, Budva, 227-30.

54. Stoltz DR, Khera KS, Bendall R, Gunner SW, 1970, Cytogenetic studies with cyclamate and related compounds, Science, 167, 1501-2.

55. Toxicological Evaluation, last updated 11/2000, Dicyclohexylamine, CAS No. 101-83-7. BG Chemie, Berufsgenossenschaft der chemischen Industrie, No. 212.

56. Van Went-de Vries GF, Freudenthal J, Hogendoorn AM, Kragten MGT, Gramberg LG, 1975, In vivo chromosome damaging effect of cyclohexylamine in the Chinese hamster, Fd Cosmet Toxicol, 13, 415-8.

57. Vucinic M, Soldatovic B, Stanimirovic Z, 1996, Robertsonian translocation T1/29 in cattle karyotype, Strategia, Faculty of Veterinary Medicine, University of Belgrade, 1-103.

58. Webster TC, 1994, Fumagillin affects Nosema apis and honey bees (Hymenoptera: Apidae), J Econ Entomol, 87, 601-4.

59. Wilkins JH, Joshi N, Margolis TP, Cevallos V, Dawson DR, 1994, Microsporidial keratoconjunctivitis treated successfully with a short course of fumagillin, Eye, 8, 703-4.

60. Winking H, Dulic B, Bulfield G, 1988, Robertsonian karyotype variation in the European house mouse Mus musculus, Z Säugetierkunde, 53, 148-61.

61. Zbinden M, Lass S, Refardt D, Hottinger J, Ebert D, 2005, Octosporea bayeri: fumidil B inhibits vertical transmission in Daphnia magna, Exp Parasitol 109, 58-61.

62. Zimonjic DB, Savkovic N, Andjelkovic M, 1990, Genotoxic agents: the effects: principles and methodology of detection. Naučna knjiga, Beograd, 1-395.

\title{
UČESTALOST HROMOZOMSKIH ABERACIJA U FUNKCIJI EVALUACIJE GENOTOKSIČNOG POTENCIJALA FUMAGILINA IN VIVO
}

\author{
STANIMIROVIĆ Z, STEVANOVIĆ JEVROSIMA, KULIĆ M i STOJIC V
}

\section{SADRŽAJ}

Dicyclohexylamin (fumagilin), kao antibiotik koga proizvodi gljivica Aspergillus fumigatus, se koristi u humanoj medicini u borbi protiv intestinalnih mikrosporidioza kod pacijenata sa HIV infekcijom, ali i za tretman obolelih od intestinalnih amebijaza i mikrosporidijanog keratokonjunktivitisa. $U$ veterinarskoj medicini efikasan je u lečenju mikrosporidioza pčela i drugih insekata uzrokovanih sa Nosema apis, N. cerani, N. bombici, ali i mikrosporidioza riba uzrokovanih sa Myxobolus cerebralis i Tetracapsuloides bryosalmonae. U ovom radu ispitivana je genotoksičnost dicikloheksilamina kvantifikacijom i kvalifikacijom hromozomskih 
aberacija u ćelijama kostne srži miševa soja BALB/c. Dicikloheksilamin je aplikovan miševima intragastrično u dozama od $25,50,75 \mathrm{mg} / \mathrm{kg}$ b.w., pri čemu je vodeno-šećerni sirup predstavljao negativnu, a cyclophosphamid ( $40 \mathrm{mg} / \mathrm{kg}$ b.w.) poozitivnu kontrolu. Utvrđeno je da samo najveća doza dicikloheksilamina signifikantno povećava učestalost $(p<0.01$ ili $p<0.001)$ numeričkih hromozomskih aberacija (aneupliodija i poliploidija) i strukturnih hromozomskih aberacija tipa gapova, prekida i centričnih ringova, u poređenju sa negativnom kontrolom. Međutim, srednja (50 mg/kg b.w.) i najviša ( $75 \mathrm{mg} / \mathrm{kg}$ b.w.) eksperimentalna doza izazvale su signifikantno $(p<0.001)$ povećanje $(7.12 \pm 0.26$ i $9.00 \pm 0.10$, respektivno) Robetrsonovih (Rb) translokacija u poređenju sa negativnom kontrolom $(0.00 \pm 0.00)$. U formiranju ovih Rb translokacija utvrđeno je da učestvuju hromozomi 4 i 19. Ovi rezultati sugerišu da je dicikloheksilamin (fumagilin) ispoljio visok genotoksični potencijal sa sposobnošću indukcije i Rb. translokacija. 